Original Research Paper

\title{
Upaya Meningkatkan Motivasi dan Pemahaman Ilmu Kimia Melalui Demonstrasi Kimia Bagi Siswa SMAN 1 Labuapi
}

\author{
Muti'ah $^{1}$, Siahaan $\mathbf{J}^{1}$, Laksmiwati $\mathbf{D}^{1}$, dan Sukib ${ }^{1}$ \\ ${ }^{1}$ Program Studi Kimia, Fakultas Keguruan dan Ilmu Pendidikan, Universitas Mataram, Mataram, Indonesia
}

DOI: https://doi.org/10.29303/jpmpi.v4i2.704

Sitasi: Muti'ah., Siahaan, J., Laksmiwati, D., \& Sukib. (2021). Upaya Meningkatkan Motivasi dan Pemahaman Ilmu Kimia Melalui Demonstrasi Kimia Bagi Siswa SMAN 1 Labuapi. Jurnal Pengabdian Magister Pendidikan IPA, 4(2)

Article history

Received: 10 Februari 2021

Revised: 29 Mei 2021

Accepted: 30 Juni 2021

*Corresponding Author:

Muti'ah, Prodi Kimia, FKIP

Universitas Mataram, Nusa

Tenggara Barat

Email:

mutiah_fkip@unram.ac.id

\begin{abstract}
Telah dilakukan kegiatan pengabdian pada masyarakat berupa pertunjukan kimia/demonstrasi kimia pada Siswa SMAN 1 Labuapi Lombok Barat. Kegiatan pengabdian ini dilakukan melalui tahapan: (1) pembuatan 2 media demonstrasi, yaitu poster kimia dan sel elektrolisis larutan KI, (2) pertunjukan pada siswa, dan (3) diskusi-tanya jawab. Hasil yang diperoleh dari kegiatan ini adalah: (1) Dua buah media demonstrasi kimia/ pertunjukan kimia, yaitu poster kimia dan sel elektrolisis larutran KI, (2) Kegiatan demonstrasi kimia dapat meningkatkan perhatian dan motivasi belajar siswa terhadap ilmu kimia cukup tinggi dilihat dari hasil observasi selama kegiatan, (3) Demonstrasi kimia dapat meningkatkan pengetahuan siswa tentang ilmu kimia terutama dalam menghubungkan antara hasil pengamatan dengan peristiwa kimia, (4) Kegiatan demonstrasi kimia dapat memotivasi siswa untuk berpikir kritis, hal ini ditunjukan oleh pertanyaan siswa yang mengaitkan antara konsep yang didemonstrasikan dengan peristiwa dalam kehidupan sehari-hari dan aspek mikroskopis dari ilmu kimia. Kesimpulan yang diperoleh menunjukan bahwa demonstrasi kimia mampu meningkatkan perhatian, motivasi, pemahaman/pengetahuan dan berpikir kritis dalam ilmu kimia pada siswa SMAN 1 Labuapi Lombok Barat.
\end{abstract}

Keywords: Demonstrasi Kimia; Motivasi; Pemahaman; Ilmu Kimia.

\section{Pendahuluan}

Ilmu kimia adalah ilmu yang mempelajari komposisi, susunan, struktur, perubahan/reaksi suatu zat/materi dan energi yang menyertainya. Oleh sebab itu perkembangan ilmu kimia cukup berperan dalam peradaban manusia, terutama bidang industri, kesehatan, makanan, pertanian, pertambangan, dan lainnya. Namun demikian ilmu kimia cenderung kurang disenangi siswa dan sulit dipahami. Sering menjadi alasan mengapa ilmu kimia kurang disenangi siswa dan sulit dipahami adalah karena ilmu kimia bersifat abstrak.

Alasan tersebut di atas tidak seluruhnya benar, karena pada dasarnya ilmu kimia membahas hal-hal nyata dan sangat erat hubungannya dengan kehidupan sehari-hari. Itulah sebabnya ilmu kimia sangat berperan dalam kemajuan ilmu dan teknologi. Oleh karena itu diperlukan suatu motivator agar siswa SMA menyenangi ilmu kimia sehingga termotivasi untuk belajar dan memahami ilmu kimia. Demonstrasi kimia bagi siswa SMA diharapkan dapat menjadi motivator dalam belajar kimia karena dapat menghubungkan ilmu kimia dengan kehidupan sehari-hari.

Menurut Achmad dan Baradja (2012) ilmu kimia adalah ilmu yang berlandaskan percobaan, oleh sebab itu pengajaran kimia di sekolah harus disertai dengan pekerjaan laboratorium. Dengan demikian dapat membangkitkan keingintahuan siswa terhadap ilmu kimia, mengenal dengan baik zat-zat yang umum dan reaksinya, lebih 
berpartisipasi, dan mengembangkan dari keadaan konkrit ke hal yang abstrak.

Menurut McKee et al. (2007) metode demonstrasi dalam pengajaran adalah cara menyampaikan informasi dengan menunjukkan sesuatu kepada siswa. Buncick et al. (2001) mendefinisikan bahwa demonstrasi kimia adalah suatu percobaan yang bertujuan untuk memperlihatkan konsep kimia tertentu. Thomson dan Soyibo (2002) menyatakan bahwa "demonstrasi kimia" merupakan media yang tepat dalam pengajaran kimia.

Kelebihan penggunaan demonstrasi kimia adalah dapat meningkatkan perhatian siswa, mendorong inklusivitas, mengembangkan konsep dan berpikir kritis, meningkatkan kemampuan observasi, menjelaskan suatu konsep dan meningkatkan kemampuan dalam mengerjakan tes hasil belajar (Chiappetta \& Koballa, 2002). Deese et al., (2000) juga melaporkan bahwa metode demonstrasi dalam pembelajaran sain/kimia dapat meningkatkan motivasi dan perhatian siswa, mengatasi miskonsepsi, meningkatkan kedisiplinan pengajar dan menjelaskan konsep abstrak. Menurut Meyer et al. (2003) dengan demonstrasi seorang guru dapat sebagai katalisator dalam mengkaitkan antara konsep pada pembelajaran sebelumnya dengan yang baru.

Hal yang harus diperhatikan dalam demonstrasi adalah cara pengajarannya, sebagaimana dilaporkan oleh Pierce dan Piecre (2007) bahwa apabila tidak disampaikan/diajarkan secara profesional, maka siswa tidak dapat belajar dari apa yang sebenarnya didemostrasikan. Baddock dan Bucat (2008) menyatakan bahwa kesalahan dalam mengajarkan dan menjelaskan demonstrasi (terutama adalah demonstrasi sangat menarik), maka dapat menjerumuskan pemahaman siswa. Berdasarkan uraian di atas, maka untuk meningkatkan motivasi belajar dan pemahaman ilmu kimia bagi siswa SMAN 1 Labuapi perlu dilakukan suatu pelatihan tentang demonstrasi kimia.

Berdasarkan latar belakang tersebut di atas dapat diidentifikasi beberapa permasalahan dan solusinya sebagai berikut: (1) Ilmu kimia di sekolah lanjutan atas SMA merupakan ilmu yang relatif baru, sehingga sebagian siswa kurang termotivasi untuk belajar dan mengalami kesulitan dalam memahaminya. (2) Untuk memotivasi dalam belajar kimia, maka diperlukan teknik penyampaian yang melibatkan siswa, membangkitkan keingintahuan siswa dan mengenalkan dengan baik zat - zat kimia umum beserta reaksinya.

Solusi yang relevan dengan permasalahan diatas yaitu memberikan demontrasi kimia, karena berdasarkan literatur demonstrasi kimia dapat meningkatkan perhatian siswa, mendorong inklusivitas, mengembangkan konsep dan berpikir kritis, meningkatkan kemampuan observasi, menjelaskan suatu konsep dan meningkatkan kemampuan dalam mengerjakan tes hasil belajar.

Manfaat dari kegiatan ini adalah: (1) Dapat menambah wawasan dan pemahaman dasar ilmu kimia bagi siswa -siswa tingkat sekolah menengah atas, sehingga mereka akan termotivasi untuk belajar ilmu kimia. (2) Diharapkan dapat menjadi acuan bagi guru SMA khususnya untuk mengajarkan ilmu kimia yang lebih menarik.

\section{Metode}

Metode yang digunakan dalam kegiatan ini adalah demonstrasi yang meliputi 2 kegiatan, yaitu: penyuluhan/ceramah dan demonstrasi kimia tentang poster kimia dan sel elektrolisis larutan kalium iodida KI.

Secara singkat, langkah-langkah penyuluan adalah sebagai berikut: (1) Menyampaikan maksud dan tujuan kegiatan, (2) Menjelaskan tentang: pengertian percobaan poster kimia dan sel elektrolisi. Setelah melakukan penyuluhan maka selanjutnya tim pengabdian melakukan demonstrasi kimia sebagai berikut:

\section{1) Poster kimia}

Alat dan bahan yang digunakan: kuas, botol penyemprot, kertas manila putih fenolftalein $1 \%$, dan $\mathrm{NaOH} 0,1 \mathrm{M}$.

Cara kerja: Tulis nama siswa atau gambar pada lembar kertas putih dengan kuas. Semprotkan $\mathrm{NaOH}$ dalam botol pada kertas tersebut, amati apa yang terjadi.

\section{2) Percobaan Elektrolisis}

Alat yang digunakan adalah: pipa $\mathrm{U}$, sumber listrik DC $12 \mathrm{~V}$, kabel, statif dan klem, elektroda karbon.

Bahan yang digunakan: larutan $250 \mathrm{~mL}$ KI 0,5 $\mathrm{M}$; indikator fenolftalein $0,1 \%$ dan indikator amilum $1 \%$.

Untuk melaksanakan demonstrasi di kelas, maka langkah-langkah yang dilakukan adalah: (1) 
Tim membagikan lembar pengamatan demonstrasi atau sejenis LKS, (2) Tim menunjukan alat dan bahan demonstrasi, peserta atau siswa mengamati alat dan bahan hasilnya dicatat dalam lembar kerja yang tersedia, (3) Tim mulai mendemonstrasikan dengan melibatkan beberapa siswa. Dalam kegiatan ini pendekatan saintifik diterapkan dengan metode tanya jawab.Dalam kegiatan tanya jawab, para peserta/siswa diwajibkan mengisi pertanyaan yang terdapat dalam lembar kerja/LKS.

\section{Hasil dan Pembahasan}

\section{Pembuatan Media Demonstrasi Kimia}

Sebelum kegiatan pertunjukan kimia/demonstrasi kimia, maka tim pengabdian melakukan percobaan/membuat media demonstrasi yaitu berupa: poster kimia dan sel elektrolisis. Poster kimia yang pada dasarnya adalah reaksi antara senyawa organik fenolftalein dengan basa $\mathrm{NaOH}$ Fenolftalein yang merupakan senyawa tidak berwarna, demikian juga $\mathrm{NaOH}$ atau $\mathrm{OH}^{-}$juga merupakan moleku/ion yang tidak berwarna. Namun demikian apabila kedua senyawa tersebut bereaksi akan membentuk struktur B yang merupakan senyawa berwarna merah. Adanya perbuhan warna tersebut karena terjadi perubahan struktur molekul fenolftalein dari gugus hidroksil menjadi quinon. Dalam prakteknya reaksi kimia tersebut terjadi pada media kerta putih.

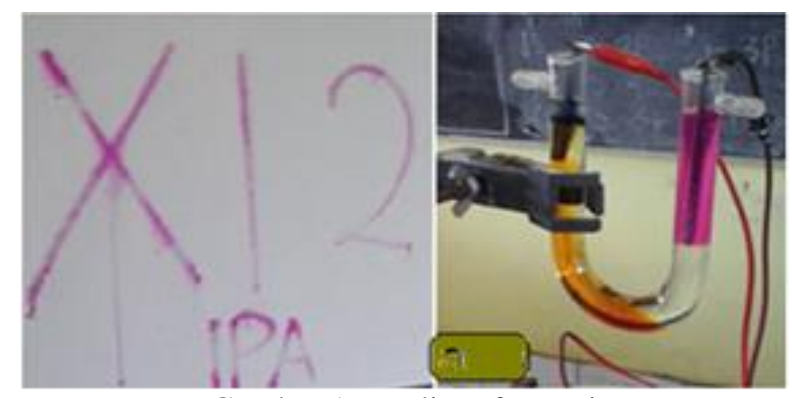

Gambar 1. Media Informasi

\section{Pertunjukkan Kimia/Demonstrasi Kimia Poster Kimia}

Pertunjukan kimia/demonstrasi kimia dilaksanakan di kelas XI IPA 1 dan 2 sebanyak 2 jenis demonstrasi, yaitu poster kimia dan sel elektrolisis.

Pada mulanya siswa kurang tertarik dengan kegiatan ini. Namun demikian setelah seorang siswa menulis dan menggambar menggunakan cairan bening, kemudian dilanjutkan penyemprotan dengan cairan bening $(\mathrm{NaOH})$, ternyata menghasilkan gambar, seluruh siswa tertegun dan diikuti suara riuh.

Setelah pertunjukan pertama yaitu poster kimia, maka hampir seluruh siswa menunjukan perhatiannya yang cukup tinggi. Bahwa sejumlah besar siswa ingin mencobanya. Bentuk perhatian siswa terhadap demonstrasi kimia bukan hanya dalam hal pertunjukannya tetapi juga ingin tahu, mengepa terjadi seperti itu. Kondisi tersebut dibuktikan dalam gambar 2, yaitu bagaimana para siswa tidak hanya memperhatikan pertunjukan, tetapi juga pengetahuan apa yang ada di dalamnya.Kegiatan yang ditunjuk-kan dalam gambar 2 adalah penjelasan mengenai apa yang terjadi saat larutan $\mathrm{NaOH}$ disemprotkan pada kertas yang mengandung fenolftalein.

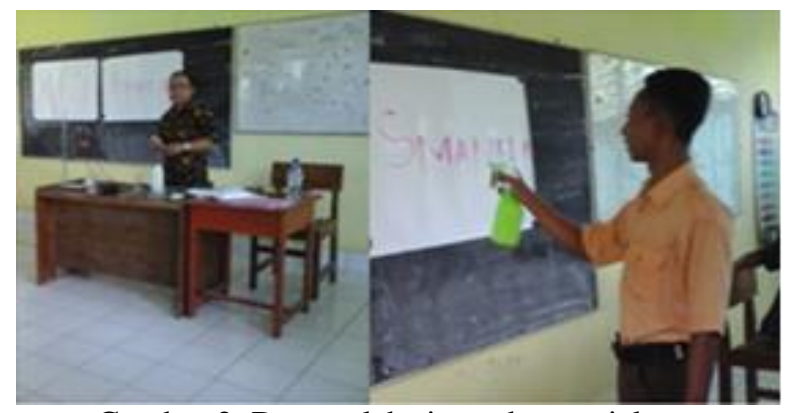

Gambar 2. Demo oleh siswa dan penjelasan

Penjelasan tersebut ditulis dalam bentuk persamaan reaksi kimia pada papan tulis. Walaupun rumus kimia/struktur molekul fenolftalein cukup kompleks namun dengan menjelaskan hal-hal berikut:

- Mengapa menggambar dengan cairan fenolftalein (tak berwarna), setelah disemprot dengan basa $\mathrm{NaOH}$ (tak berwarna) menjadi berwarna merah?

Dari hasil pengamatan ternyata para siswa dapat memahaminya. Hal ini terlihat dari foto kegiatan dimana para siswa terlihat memperhatikan dengan baik. Siswa juga terlihat menunjukan perhatian yang cukup tinggi dan adanya motivasi untuk bertanya. Beberapa siswa mengajukan pertanyaan yang cukup menarik bagi perkembangan pengajaran ilmu kimia. 


\section{Sel Elektrolisis}

Pada awal sebelum demonstrasi diajukan beberapa pertanyan oleh tim, yaitu:

(1) Apakah siswa telah mengenal $\mathrm{NaOH}$ atau basa?

(2) Apakah siswa mengenal gas hydrogen

(3) Apakah siswa telah mengenal unsure iodium?

Selanjutnya tim menyatakan bahwa zat-zat tersebut dapat dibuat secara kimia, yang dalam hal ini menggunakan cara elektrolisis. Demonstrasi kimia tentang sel elektrolisis, yaitu proses elektrolisis larutan KI (pembuatan Iodium $\mathrm{I}_{2}$ ). Perhatian siswa terhadap demonstrasi ini cukup tinggi. Hal ini ditunjukan oleh kondisi siswa saat demonstrasi dan motivasi bertanya kepada tim kegiatan Beberapa pertanyaan yang diajukan siswa antara lain: mengapa bagian karbon negatif terbentuk warna merah, mengapa terjadi gelembung gas, mengapa warna di sekitar karbon (+) terbentuk warna ungu, mengapa setelah ditetesi amilum memberikan warna biru kehitaman?

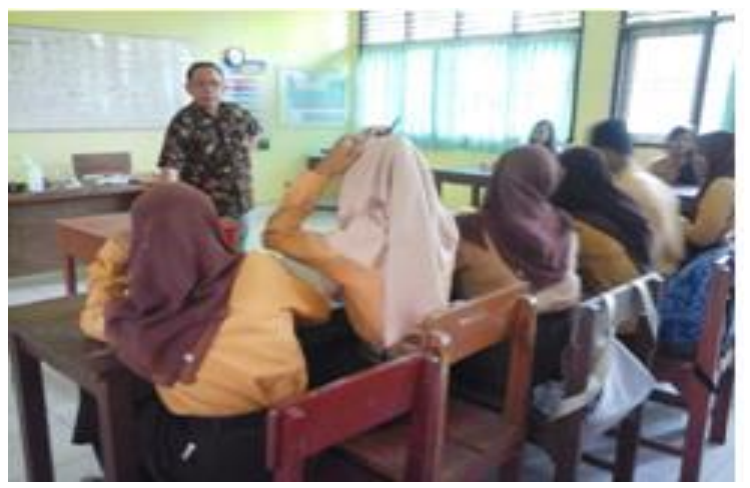

Gambar 3. Diskusi siswa dan Tim

\section{Diskusi dan Tanya Jawab}

Kegiatan diskusi diawali dengan permasalahan: "mengapa tulisan/gambar yang tak berwarna menjadi berwarna" Beberapa jawaban siswa antara lain karena indikator dalam basa bereaksi dengan basa berwarna merah. Selanjutnya tim pengabdian menambahkan penjelasan yang melibatkan perubahan struktur senyawa. Langkah yang dilakukan adalah menanyakan apa perbedaan struktur yang tidak berwarna dan yang berwarna. Namun demikian tim tetap mengarahkan satu per satu mengenai struktur molekul fenolftalen. Siswa tidak dituntut memberi nama atau gugus apa saja yang berbeda, namun

hanya secara riil yang terlihat dari gambar struktur tersebut.

Hampir lebih dari 70\% siswa dapat menjawabnya dengan baik yaitu: (1) senyawa sebelum disemprot (A) mengandung $\mathrm{OH}$ dan setelah disemprot (B) tidak ada, (2) jumlah ikatan rangkap di A sebanyak 3, sedangkan di B hanya 2 , (3) ada Na pada B tetapi tidak ada di A, (4) ada ikatan $O$ dengan $C$ pada A tetapi tidak ada di $B$.

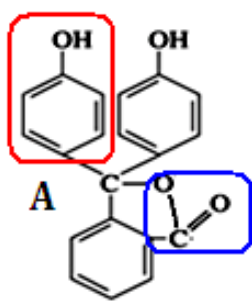

\section{Sebelum disemprot Setelah disemprot}

Selanjutnya tim peneliti mengajukan pertanyaan apa yang menyebabkan terbentuknya warna pada senyawa setelah disemprot (B)? (ditambah zat warna, akibat pengeringan, adanya perubahan struktur molekul/zat?) tenyata hampir seluruh siswa menjawab adanya perubahan struktur molekul. Beberapa pertanyaan ada yang bersifat pengembangan, misalnya dari salah satu siswa adalah: apakah zat warna ini dapat dimakan? pertanyaan tersebut menunjukan rasa ingin tahu siswa meningkat. Ada pertanyaan lagi yang menunjukan adanya motivasi belajar, yaitu “ apakah kita dapat memperoleh warna selain warna merah.

Diskusi tentang sel elektrolisis diawali dengan pertanyaan: "Mengapa bagian karbon negatif terbentuk warna merah" Pertanyaan tersebut dijawab dijawab dengan menjelaskan proses elektrolisis sebagai berikut:

Elektrolisis adalah peristiwa/proses penggunaan energi listrik untuk berlangsungnya reaksi kimia. Misalnya dengan adanya arus listrik, maka larutan KI dalam air dapat menglami reaksi umum sebagai berikut:

$$
2 \mathrm{KI}+2 \mathrm{H}_{2} \mathrm{O} \stackrel{\text { Listrik }}{\longrightarrow} 2 \mathrm{KOH}+\mathrm{H}_{2}(\mathrm{~g})+\mathrm{I}_{2}
$$

Reaksi tersebut terjadi dalam sebuah sel yang terdiri dari: elektroda (katoda dan anoda), larutan KI, penghantar, dan sumber arus. Reaksi kimia terjadi pada ke dua elektroda, yaitu: 
Anoda (+): raksi oksidasi:

$$
2 \mathrm{I}_{(\mathrm{aq})}^{-} \quad \rightarrow \mathrm{I}_{2}+2 \mathrm{e}
$$

Katoda (-): reaksi reduksi:

$$
2 \mathrm{H}_{2} \mathrm{O}+2 \mathrm{e} \rightarrow 2 \mathrm{OH}_{(\mathrm{aq})}^{-}+\mathrm{H}_{2(\mathrm{~g})}
$$

Dari percobaan menunjukan bahwa di bagian karbon (-) terbentuk warna merah karena terbentuk ion $\mathrm{OH}$ - dapat bereaksi dengan indikator fenolftalein yang menunjukan warna merah anggur, dan di bagian karbon (-) terbentuk gelembung gas. Dari persamaan reaksi yang terbentuk, maka gas yang terbentuk adalah gas hidrogen.

Pertanyaan berikutnya adalah "Mengapa warna di sekitar karbon $(+)$ terbentuk warna ungu". Pertanyaan tersebut juga dijawab berdasarkan persamaan reaksi tersebut. Dengan menunjukan persamaan reaksi maka siswa mampu memprediksi jawaban yaitu terbentuk iodium. Namun demikian siswa belum mengetahui bahwa bila iodium bereaksi dengan amilum maka akan terbentuk warna biru.

Berdasarkan hasil tanya jawab tersebut menunjukan bahwa siswa mulai berpikir kritis yaitu mampu menghubungkan hasil pengamatan dengan peristiwa kimia. Beberapa hal yang menarik adalah adanya pertanyaan yang terkait dengan konsep-konsep dasar elektrolisis, yaitu istilah elektroda, katoda, anoda, reaksi oksidasi, dan reduksi.

\section{Kesimpulan}

Dari hasil kegiatan pengabdian masyarakat ini dapat diambil beberapa kesimpulan, yaitu:

1. Telah berhasil dibuat 2 buah media demonstrasi kimia/pertunjukan kimia, yaitu poster kimia dan sel elektrolisis larutan kalium iodida. Media demonstrasi kimia tersebut telah diuji coba dan dipertunjukan pada siswa SMAN 1 Labuapi, Lombok Barat.

2. Hasil kegiatan menunjukan bahwa melalui kegiatan demonstrasi kimia, perhatian dan motivasi belajar siswa terhadap ilmu kimia cukup tinggi dilihat dari hasil observasi selama kegiatan

3. Hasil kegiatan menunjukan bahwa kegiatan demonstrasi kimia dapat meningkatkan pengetahuan ilmu kimia terutama dalam menghubungkan antara hasil pengamatan dengan peristiwa kimia yang ditunjukan oleh hasil diskusi dan tanya jawab

4. Hasil kegiatan demonstrasi dapat memotivasi siswa untuk berpikir kritis, hal ini ditunjukan oleh pertanyaan siswa yang mengaitkan antara konsep yang didemonstrasikan dengan peristiwa dalam kehidupan sehari-hari

\section{Ucapan Terima Kasih}

Penulis mengucapkan terima kasih kepada Ketua Lembaga Penelitian dan Pengabdian kepada Masyarakat Universitas Mataram yang telah memberikan segala fasilitas, sehingga kegiatan ini dapat terlaksana dengan baik.

\section{Daftar Pustaka}

Achmad dan Baradja. 2013. Demonstrasi Sains Kimia. Nuansa, Ujungberung Bandung

Buncick, M.C., Betts, P.G., \& Horgan, D.D. (2001). Using demonstrations as a contextual road map: enhancing course continuity and promoting active engagement in introductory college physics. International Journal of Science Education. 23(12), 1237-1255.

Chiappetta, E.L., and T.R. Koballa. 2002. Science instruction in the middle and secondary schools. Upper Saddle River, NJ: PrenticeHall

Deese WC, Ramsey LL, Walczyk J, Eddy D (2000) Using demonstration assessments to improve learning. J Chem Educ 77:1511

McKee, E., F.M., Williamson, dan L.E. Ruebush. 2007. Effects of a Demonstration Laboratory on Student Learning. J. Sci Educ Technol, 16:395-400

Meyer, L. S., Schmidt, S., Nozawa, F., Panee, D., \& Kisler, M. 2003. Using demonstrations to promote student comprehension in chemistry. Journal of Chemical Education. 80(4), 431-435.

Pierce, D. T., \& Pierce, T. W. 2007. Effective use of demonstration assessments in the classroom relative to laboratory topics. 
Journal of Chemical Education. 84(7), 11501155

Thompson, J., dan Soyibo, K. 2002. Effects of lecture, teacher demonstrations, discussion and practical work on 10th grader's attitudes to chemistry and understanding of electrolysis. Research in Science \& Technological Education, 20(1), 25-35 